\title{
PENGARUH PERLAKUAN AWAL BAHAN BAKU DAN WAKTU DESTILASI SERAI DAPUR (Cymbopogon citratus) TERHADAP KARAKTERISTIK FISIKOKIMIA MINYAK SERAI DAPUR (Lemongrass oil)
}

\author{
THE EFFECT OF DISTILLATION TIME AND RAW MATERIAL PRETREATMENT \\ ON PHYSICOCHEMICAL CHARACTERISTIC OF LEMONGRASS OIL \\ (Cymbopogon citratus)
}

\author{
Kawiji $^{1)}$, Lia Umi Khasanah ${ }^{1}$, dan Christian Argo Pramani ${ }^{2)}$ \\ 1) Staf Pengajar Jurusan Ilmu dan Teknologi Pangan, Fakultas Pertanian, \\ Universitas Sebelas Maret, Surakarta \\ ${ }^{2)}$ Mahasiswa Program Studi S-1 Teknologi Hasil Pertanian, Fakultas Pertanian, \\ Universitas Sebelas Maret, Surakarta
}

\begin{abstract}
Lemongrass oil can be produced from distillation process of lemongrass stem. Lemongrass oil in chemical industries is used as raw material to produce cosmetic, perfume, deodorant, soap perfume, floor washer and detergent. The aim of this research was to know the effect of distillation time and raw material pretreatment on physicochemical characteristic of lemongrass oil. The experiment design of this research was completely randomized designed with factorial arrangement of 2 factor that was the pretreatment variation of raw material (carved and strike) and distillation time variation (1,2, 3 and 4 hours). The results which were obtained including total soluble solid, color, odor, rendemen, specific gravity on $25{ }^{\circ} \mathrm{C}$, optical rotation, refractive index on $20^{\circ} \mathrm{C}$, solubility in $70 \%$ ethanol and citral content. The result of this research, showed that the pretreatment of raw material and the distillation time influenced on total soluble solid, odor, rendemen, specific gravity on 25 ${ }^{\circ} \mathrm{C}$, optical rotation, refractive index on $20{ }^{\circ} \mathrm{C}$, solubility in $70 \%$ ethanol and uninfluenced on color and citral content. With carve treatment and longer distillation time caused increasing of total soluble solid, odor, rendemen, specific gravity on $25{ }^{\circ} \mathrm{C}$, optical rotation, refractive index on $20{ }^{\circ} \mathrm{C}$ more significant compared to strike treatment on the equal distillation time, whereas solubility on ethanol decreased. Carve treatment with 4 hours distillation time was the most optimum time and treatment to produce better lemongrass oil, that was total soluble solid $80,533{ }^{\circ} \mathrm{Brix}$, color 0,5456 A, odor of lemon, rendemen $0,303 \%$, specific gravity on $25^{\circ} \mathrm{C} 0,8796$ $\mathrm{gr} / \mathrm{ml}$, optical rotation $+0,21$, refractive index on $20{ }^{\circ} \mathrm{C} 1,4575$, solubility in $70 \%$ ethanol 1: 4,33 and citral content $76,3 \%$.
\end{abstract}

Keywords : carve, lemongrass oil, distillation time, strike.

\begin{abstract}
ABSTRAK
Minyak atsiri dari serai dapur dapat diperoleh dengan proses destilasi batang serai dapur. Minyak serai dapur dalam industri kimia dimanfaatkan sebagai bahan baku dalam pembuatan kosmetik, parfum, deodoran, pewangi sabun, pembersih lantai dan deterjen. Tujuan penelitian ini adalah untuk mengetahui apakah perlakuan awal bahan baku dan waktu destilasi serai dapur berpengaruh terhadap karakteristik fisikokimia minyak serai dapur yang dihasilkan. Rancangan percobaan berupa rancangan acak lengkap (RAL) faktorial dengan 2 faktor yaitu; variasi perlakuan awal bahan baku (dengan dimemarkan dan dengan dirajang) dan variasi waktu destilasi (1, 2, 3 dan 4 jam). Data diperoleh dari analisa; Total padatan terlarut, warna, aroma, rendemen, berat jenis pada $25^{\circ} \mathrm{C}$, putaran optik, index bias pada $20^{\circ} \mathrm{C}$, kelarutan dalam alkohol $70 \%$ dan kadar sitral. Berdasarkan hasil penelitian dapat disimpulkan bahwa perlakuan awal bahan baku dan waktu destilasi berpengaruh terhadap total padatan terlarut, aroma, rendemen, berat jenis, putaran optik, indek bias dan tidak berpengaruh terhadap warna dan kadar sitral. Dengan perlakuan perajangan dan waktu destilasi yang lebih lama menyebabkan terjadi peningkatan nilai total padatan terlarut, aroma, rendemen, berat jenis, putaran optik, indek bias yang lebih signifikan dibandingkan dengan dimemarkan pada waktu destilasi yang sama, sedangkan kelarutannya dalam alkohol cenderung menurun. Perlakuan perajangan dengan waktu destilasi selama 4 jam merupakan perlakuan dan waktu yang paling optimal untuk menghasilkan minyak serai dapur yang lebih baik, yakni; dengan nilai total padatan terlarut $80,533{ }^{\circ}$ Brix, warna $0,5456 \AA$, aroma lemon, rendemen $0,303 \%$, berat jenis pada $25^{\circ} \mathrm{C} 0,8796$ gr $/ \mathrm{ml}$, putaran optik $+0,21$, indek bias pada $20^{\circ} \mathrm{C} 1,4575$, kelarutan dalam alkohol $70 \% 1: 4,33$ dan kadar sitral 76,3\%.
\end{abstract}

Kata kunci : dimemarkan, minyak serai dapur, perajangan, waktu destilasi 


\section{PENDAHULUAN}

Serai dapur (Cymbopogon citratus) termasuk dalam 5 tanaman utama diantara bermacam-macam tanaman di daerah tropis selain kunyit, temulawak, kencur, akar wangi, lengkuas dan lain-lain. Serai dapur merupakan salah satu komoditi yang mempunyai potensi untuk dikembangkan penggunaannya, baik sebagai bahan makanan maupun sebagai bahan baku industri. Sebagai bahan makanan, serai dapur banyak digunakan sebagai bumbu dalam beberapa makanan olahan. Sedangkan sebagai bahan baku industri serai dapur dapat diolah menjadi minyak serai dapur maupun menjadi sitral. Pengembangan serai dapur disamping memberikan komoditi alternatif kepada petani, juga merupakan diversifikasi ekspor yang berarti akan menjadi salah satu sumber devisa di sektor nonmigas.

Menurut Harris (1993), produksi minyak serai dapur (Lemongrass oil) di dunia diperkirakan mencapai 500 ton/tahun, dengan negara produsen utamanya India dan Guatemala, namun Indonesia baru bisa memproduksi minyak ini dalam jumlah yang tidak tetap dan ekspor hanya berkisar antara 2-3 ton minyak/tahunnya.

Pada tahun 1990, kebutuhan dunia akan minyak serai dapur berkisar antara 8001300 ton/tahun. Bahkan pada tahun 2000 permintaan minyak serai dapur di dunia meningkat menjadi 2000 ton/tahun dengan harga pasaran internasionalnya mencapai 11 US \$/kg minyak (Feryanto, 2006).

Dalam rangka peningkatan nilai tambah dari tanaman serai dapur ini, maka berbagai usaha telah dilakukan, salah satu diantaranya adalah mengekstraknya menjadi minyak atsiri. Minyak atsiri serai dapur, saat ini merupakan salah satu komoditi ekspor yang sangat potensial, mengingat kebutuhan dunia akan minyak ini relatif sangat besar dan permintaannya dari tahun ke tahun juga meningkat sedangkan negara produsennya masih sangat terbatas. Untuk itu sangat dipandang perlu untuk melakukan berbagai upaya untuk mengusahakannya secara komersial. Serai dapur yang ada di negara kita tersebar diseluruh pelosok negeri, jika dimanfaatkan sebagai lemongrass oil maka dapat meningkatkan nilai ekonomisnya dan harus menyesuaikan kualitasnya dengan standar mutu perdagangan dunia, sehingga komoditi ini mampu untuk berkompetisi di dunia internasional.

\section{METODE PENELITIAN}

\section{Bahan}

Bahan utama yang digunakan adalah serai dapur (Cymbopogon citratus). Bahan ini diperoleh dari salah satu pasar tradisional di daerah Matesih, Karanganyar, Solo, Jawa tengah.

Penentuan semua parameter analisa minyak serai dapur menggunakan metode Guenther dengan bahan untuk analisa penampilan, rendemen, putaran optik dan index bias adalah minyak serai dapur. Bahan untuk analisa warna adalah alkohol $90 \%$ dan minyak serai dapur. Bahan untuk analisa kelarutan minyak dalam alkohol dan aroma adalah minyak serai dapur dan alkohol $70 \%$. Bahan untuk analisa berat jenis adalah aquades dan minyak serai dapur. Bahan untuk analisa kadar sitral adalah aquades, minyak serai dapur dan Natrium Bisulfit jenuh $\left(\mathrm{Na}_{2} \mathrm{SO}_{3}\right)$.

\section{Metode}

Ada 2 tahap utama yang harus dilakukan dalam penelitian ini yaitu tahap preparasi bahan dan pembuatan minyak serai dapur. Tahap preparasi bahan dilakukan dengan mencuci serai dapur hingga bersih, setelah bersih, dilakukan variasi perlakuan awal bahan baku yaitu; serai dapur dengan dimemarkan dan dengan proses perajangan. Untuk serai dapur dengan dimemarkan dilakukan dengan mememarkan serai dapur dengan menggunakan martil seberat $1 \mathrm{~kg}$. Adapun intensitas pemukulannya sama yaitu 5 kali pemukulan perbatang serai dengan melibatkan semua bagian dari serai tersebut sehingga diharapkan serai yang dimemarkan memiliki tingkat pememaran yang sama/seragam. Sedangkan untuk serai dapur dengan proses perajangan dilakukan dengan merajang serai dapur dengan menggunakan pisau. Adapun serai dapur tersebut dirajang dengan posisi tegak dengan masing-masing ketebalan rajangan $10 \mathrm{~mm}$. 
Tahap selanjutnya adalah pembuatan minyak serai dapur. Pembuatan minyak serai dapur dilakukan dengan metode direct destillation Guenther (1987) yang dimodifikasi. Bagian pangkal serai dapur didestilasi hingga seluruh minyak terekstrak semua. Minyak dipisahkan dari pelarutnya dengan menggunakan corong pemisah.

Analisa data yang dilakukan berupa analisa Total padatan terlarut (Refraktro), Warna (Spektrofotometer), Aroma (Organoleptik), Rendemen (Guenther), Berat Jenis Pada Suhu $25^{\circ} \mathrm{C}$ (Guenther), Putaran optik(Guenther), Indek bias(Guenther), Kelarutan dalam Alkohol 70 \%(Guenther), dan Kadar Sitral (Bisulfit).

\section{Pengujian Total padatan terlarut (Refraktro)}

Ambil sampel minyak serai dapur dengan pipet kemudian masukkan ke dalam prisma refraktrometer. Tera total padatan terlarutnya dengan refraktrometer pada kondisi ruang cukup sinar matahari.

\section{Pengujian Warna (Spektrofotometri)}

0,2 minyak serai dapur diencerkan 10 $\mathrm{ml}$ metanol PA. Diambil $1 \mathrm{ml}$ ditera dengan spektrofotometer pada panjang gelombang $516 \mathrm{~nm}$

\section{Pengujian Aroma(Organoleptik)}

Siapkan sampel minyak serai dapur berdasarkan jumlah perlakuannya yaitu 8 sampel minyak serai dapur. Lalu siapkan 6 sampel ekstrak lemon dengan tingkat konsentrasi yang berbeda-beda.

Ekstrak lemon $\mathrm{I}=13,216 \%(\mathrm{~b} / \mathrm{v})$

Ekstrak lemon II $=16,232 \%(\mathrm{~b} / \mathrm{v})$

Ekstrak lemon III $=39,648 \%(\mathrm{~b} / \mathrm{v})$

Ekstrak lemon IV $=52,864 \%(\mathrm{~b} / \mathrm{v})$

Ekstrak lemon $\mathrm{V}=66,080 \%(\mathrm{~b} / \mathrm{v})$

Ekstrak lemon VI $=79,296 \%(\mathrm{~b} / \mathrm{v})$

\section{Penentuan Rendemen (Metode Guenther)}

Rendemen merupakan kadar

kandungan minyak serai dapur di dalam batang serai dapur yang dinyatakan dengan persen.

Hasilnya dihitung dengan rumus :

$\%$ minyak $=\frac{\mathrm{kg} \text { bahan }}{\text { ml destilat }} \times \quad 100 \%$
Penentuan Berat Jenis Pada Suhu $25{ }^{\circ} \mathrm{C}$ (Metode Guenther)

Berat jenis sampel dapat didefinisikan sebagai perbandingan dari berat sampel dengan berat air dalam volume dan suhu yang sama. $1 \mathrm{ml}$ aquades yang diambil dengan pipet volume $1 \mathrm{ml}$ ditimbang beratnya. Selanjutnya ambil $1 \mathrm{ml}$ minyak serai dapur dengan pipet volume $1 \mathrm{ml}$ dan ditimbang beratnya. Berat jenis minyak tersebut adalah hasil bagi dari berat minyak dengan berat aquades dalam volume dan suhu yang sama atau hasilnya dihitung dengan rumus sebagai berikut :

Koreksi temperatur pembacaan ketemperatur standard yang diinginkan dirumuskan (AOAC, 1970).

Berat jenis $\left(25^{\circ} \mathrm{C}\right)=$ Berat jenis $\left(\mathrm{T}^{\circ} \mathrm{C}\right)+$ $0,00064(\mathrm{~T}-25)$

\section{Penentuan Putaran Optic (Metode Guenther)}

Tempatkan tabung polarimeter 100 $\mathrm{mm}$ yang berisi minyak dibawah alat pemeriksa diantara polaliser dan analiser. Putar analiser secara perlahan-lahan sampai setengahnya dapat dilihat melalui teleskop dan intensitas sinarnya sama dengan penerangannya. Selanjutnya akan terlihat arah rotasi kekanan/kekiri berdasarkan intensitas penerangannya dari kedua bidang. Kalau memutar bidang kekanan disebut dekstro (+), kalau memutar bidang kekiri disebut laevo(-). Nilai derajat/sudut putarnya dapat dilihat dengan teleskopnya.

\section{Penentuan Indek bias (Metode Guenther)}

Tempatkan refraktrometer ditempat yang terkena sinar matahari. Kedalam prisma dialirkan air pada suhu $20 \mathrm{C}$ dan dibersihkan dengan alkohol dan eter. Tuangkan minyak kedalam prisma/diglab kemudian prisma ditutup rapat dengan memutar sekrup. Gerakkan Alidade maju/mundur. Atur garis pembatasnya. Nilai indekbias dapat dibaca langsung setelah tercapai suhu yang setimbang.

Pengujian Kelarutan dalam Alkohol 70 \% (Metode Guenther)

minyak diambil sebanyak $1 \mathrm{ml}$, masukkan dalam tabung reaksi ditambah 
alkohol $70 \%$ sedikit demi sedikit sampai terbentuk larutan jernih. Setiap penambahan alkohol tabung reaksi dikocok atau digoyang-goyang. Kelarutan dalam alkohol dinyatakan dalam jumlah alkohol yang dibutuhkan untuk melarutkan $1 \mathrm{ml}$ minyak. Semakin besar kelarutan minyak dalam alkohol, semakin baik mutunya. Kelarutan minyak dalam alkohol dinyatakan sebagai berikut;

Kelarutan dalam $70 \%$ alkohol $=1$ Volume dalamY Volume

Penentuan Kadar Sitral (Metode Bisulfit)

Ke dalam labu cassia $150 \mathrm{ml}$ dimasukkan $75 \mathrm{ml}$ larutan Natrium bisulfit jenuh kemudian tambahkan $10 \mathrm{ml}$ minyak serai dapur ke dalam labu lalu dikocok, labu kemudian dipanaskan selama 6 jam pada suhu $60 \mathrm{C}$, setelah labu dingin ukur minyak yang tak bereaksi.

$$
\begin{aligned}
\text { Kadar sitral }= & 10(10-\text { jumlah minyak } \\
& \text { yang tidak bereaksi })
\end{aligned}
$$

Rancangan pecobaan berupa rancangan acak lengkap dengan 2 faktor yaitu; variasi perlakuan awal bahan baku (dimemarkan, dirajang) dan variasi waktu destilasi (1 jam, 2 jam, 3 jam, dan 4 jam). Data yang di peroleh selanjutnya dianalisa dengan menggunakan ANOVA. Apabila terdapat perbedaan dilanjutkan dengan uji beda nyata menggunakan Duncan Multiple Range Test (DMRT) pada tingkat signifikansi $\alpha=0,05$.

\section{HASIL DAN PEMBAHASAN}

\section{Total padatan terlarut}

Penampilan merupakan suatu parameter untuk menilai wujud bentuk luar dari suatu bahan. Wujud cair dari minyak serai dapur dapat dilihat dari tingkat total padatan terlarutnya. Kekentalan minyak menunjukkan total padatan terlarut yang terkandung di dalam minyak yang dinyatakan dalam ${ }^{\circ}$ Brix.

Pada Tabel 1 hasil analisa statistik yang dilakukan dengan tingkat ketelitian 95 persen menunjukkan bahwa perlakuan awal bahan baku, waktu destilasi, serta interaksi antar keduanya yang berbeda memberikan pengaruh yang berbeda terhadap total padatan terlarut minyak serai dapur yang dihasilkan. Perlakuan awal bahan baku dengan dirajang menunjukkan nilai total padatan terlarut yang lebih tinggi jika dibandingkan dengan dimemarkan.

Tabel 1. Hasil analisa total padatan terlarut minyak serai dapur $\left({ }^{\circ} \mathrm{Brix}\right)$

\begin{tabular}{ccc}
\hline \hline Waktu & \multicolumn{2}{c}{ Perlakuan awal bahan baku(A) } \\
\cline { 2 - 3 } destilasi & $\begin{array}{c}\text { Dimemarkan } \\
(B)\end{array}$ & Dirajang $\left(\mathrm{A}_{2}\right)$ \\
\hline 1 jam( $\left(\mathrm{B}_{1}\right)$ & $79,066^{\mathrm{a}}$ & $79,266^{\mathrm{a}}$ \\
2 jam $\left(\mathrm{B}_{2}\right)$ & $79,667^{\mathrm{b}}$ & $79,266^{\mathrm{a}}$ \\
3 jam $\left(\mathrm{B}_{3}\right)$ & $80,066^{\mathrm{cd}}$ & $80,266^{\mathrm{d}}$ \\
4 jam $\left(\mathrm{B}_{4}\right)$ & $80,200^{\mathrm{d}}$ & $80,533^{\mathrm{e}}$ \\
\hline \hline
\end{tabular}

Perlakuan dengan dirajang menunjukkan nilai total padatan telarut yang lebih tinggi jika dibandingkan dengan dimemarkan. Dengan perlakuan perajangan cenderung lebih memudahkan difusi pelarut ke bahan dan proses pengeluaran minyak atsiri yang terdapat dalam kelenjar minyak ke permukaan bahan. Menurut Ketaren (1987), pengecilan ukuran dengan perajangan menyebabkan terikutnya sejumlah kecil residu kental yang bertitik didih tinggi seperti; resin, parafin, lilin (wax) dan lemak dari kelenjar minyak lalu bercampur dan larut bersama minyak atsiri, kemudian ikut terdestilasi sehingga akan meningkatkan total padatan terlarut pada minyak yang dihasilkan.

Peningkatan total padatan terlarut minyak seiring dengan peningkatan waktu destilasi dapat terjadi karena proses pemanasan yang berlangsung selama proses destilasi. Pemanasan menyebabkan sebagian kecil komponen minyak atsiri mengalami polimerisasi. Komponen-komponen minyak atsiri yang mengalami polimerisasi adalah dari golongan senyawa hidrokarbon takteroksigenasi seperti; senyawa terpen dan sesquiterpen. Polimerisasi minyak menyebabkan terbentuknya senyawasenyawa polimer dalam minyak yang akan memicu meningkatkan nilai total padatan terlarut minyak. Selain karena proses polimerisasi, peningkatan total padatan terlarut minyak juga disebabkan oleh sejumlah kecil fraksi berat ikut tersuling 
selama proses destilasi. Menurut Feryanto (2006), pemanasan dengan suhu dan tekanan yang tinggi akan menyebabkan sejumlah komponen senyawa berantai panjang yang memiliki titik didih tinggi menjadi ikut tersuling bersama minyak. Fraksi berat tersebut seperti; parafin, lilin (wax) dan senyawa resin. Parafin merupakan senyawa dari golongan alkana berantai panjang yang terdapat dalam jaringan lemak tanaman aromatik kemudian larut bersama minyak atsiri. Semakin lama waktu destilasi maka akan meningkatkan total padatan terlarut di dalam minyak sehingga akan meningkatkan kekentalan minyak.

Interaksi antara keduanya, yaitu perlakuan awal bahan baku dan waktu destilasi yang berbeda menghasilkan total padatan terlarut yang berbeda nyata, namun perbedaannya tidak terlalu signifikan.

Pada penelitian ini, nilai total padatan terlarut minyak serai dapur yang dihasilkan berkisar antara 79,066 - 80,533 ${ }^{\circ}$ Brix, sedangkan menurut standar EOA yang dipersyaratkan penampilannya cair (EOA, 1975) dan menurut standar SNI yang dipersyaratkan penampilannya cair (SNI, 1995). Dari beberapa perlakuan awal bahan baku dan waktu destilasi minyak serai dapur semua memenuhi standar mutu EOA maupun SNI yaitu penampilannya cair, meskipun kisaran nilai antara $79,066-80,533{ }^{\circ}$ Brix menunjukkan sifat cairan yang pekat.

\section{Warna}

Warna merupakan parameter penting dalam menentukan kualitas minyak. Intensitas warna minyak ditentukan oleh banyak/sedikitnya kandungan pigmen warna tertentu di dalam minyak. Intensitas warna diukur dengan spektrofotometer dan nilainya dinyatakan dengan tingkat Absorbansi $(\AA ̊)$.

Tabel 2. Hasil analisa warna minyak serai dapur $(\AA)$

\begin{tabular}{ccc}
\hline \hline $\begin{array}{c}\text { Waktu } \\
\text { destilasi } \\
(\mathrm{B})\end{array}$ & \begin{tabular}{c} 
Perlakuan awal bahan baku(A) \\
\cline { 2 - 3 }$\left(\mathrm{A}_{1}\right)$
\end{tabular} \\
\hline 1 jam $\left(\mathrm{B}_{1}\right)$ & $0,5135^{\mathrm{a}}$ & $0,5133^{\mathrm{a}}$ \\
2 jam $\left(\mathrm{B}_{2}\right)$ & $0,5260^{\mathrm{b}}$ & $0,5256^{\mathrm{b}}$ \\
$3 \mathrm{jam}\left(\mathrm{B}_{3}\right)$ & $0,5341^{\mathrm{c}}$ & $0,5357^{\mathrm{c}}$ \\
$4 \mathrm{jam}\left(\mathrm{B}_{4}\right)$ & $0,5439^{\mathrm{d}}$ & $0,5456^{\mathrm{d}}$ \\
\hline \hline
\end{tabular}

Hasil analisa statistik yang dilakukan dengan tingkat ketelitian 95 persen pada Tabel 2 menunjukkan bahwa perlakuan awal bahan baku, waktu destilasi, serta interaksi antar keduanya yang berbeda tidak memberikan pengaruh yang berbeda terhadap absorbansi warna minyak serai dapur yang dihasilkan. Perlakuan awal bahan baku dengan dirajang menunjukkan nilai absorbansi warna yang lebih tinggi jika dibandingkan dengan dimemarkan.

Perlakuan dengan dirajang menunjukkan nilai absorbansi warna yang lebih tinggi jika dibandingkan dengan dimemarkan. Dengan perlakuan perajangan cenderung lebih memudahkan difusi pelarut ke bahan dan proses pengeluaran minyak atsiri yang terdapat dalam kelenjar minyak ke permukaan bahan. Pengecilan ukuran dengan perajangan menyebabkan terikutnya sejumlah kecil pigmen warna merah yang secara alami terikat dalam jaringan lemak lalu bercampur dan larut bersama minyak atsiri, kemudian ikut terdestilasi sehingga meningkatkan intensitas warna merah pada minyak yang dihasilkan.

Peningkatan nilai absorbansi minyak seiring dengan peningkatan waktu destilasi dapat terjadi karena semakin lama waktu kontak antara bahan sumber minyak dengan pelarut sehingga pigmen alami warna merah lebih mudah terekstrak, terakumulasi dan ikut terdestilasi bersama minyak atsiri. Semakin lama waktu destilasi maka akan meningkatkan intensitas warna merah dari minyak serai dapur yang dihasilkan.

Interaksi antara keduanya, yaitu perlakuan awal bahan baku dan waktu destilasi yang berbeda menghasilkan nilai absorbansi warna yang tidak berbeda nyata.

Pada penelitian ini, nilai absorbansi warna minyak serai dapur yang dihasilkan berkisar antara 0,5133-0,5456 $\AA$, sedangkan menurut standar EOA yang dipersyaratkan warnanya antara kuning tua sampai merah (EOA, 1975) dan menurut standar SNI yang dipersyaratkan warnanya antara kuning tua sampai merah (SNI, 1995). Dari penelitian analisa warna pada $\lambda=516 \mathrm{~nm}$ didapatkan range absorbansi antara 0,5133-0,5456 $\AA$, secara visual menunjukkan warna merah. Untuk range panjang gelombang warna 
kuning sampai merah yaitu berkisar antara 500-620 nm. Dari beberapa perlakuan awal bahan baku dan waktu destilasi minyak serai dapur semua memenuhi standar mutu EOA maupun SNI yaitu warnanya antara kuning tua sampai merah.

\section{Aroma}

Aroma merupakan salah satu parameter mutu minyak atsiri. Aroma dari suatu minyak dipengaruhi oleh senyawasenyawa yang terkandung didalamnya.

Tabel 3. Hasil analisa organoleptik aroma minyak serai dapur

\begin{tabular}{ccc}
\hline \hline Waktu & \multicolumn{2}{c}{ Perlakuan awal bahan } \\
Destilasi (B) & \multicolumn{2}{c}{ baku(A) } \\
\cline { 2 - 3 } & $\begin{array}{c}\text { Dimemarkan } \\
\left(\mathrm{A}_{1}\right)\end{array}$ & $\begin{array}{c}\text { Dirajang } \\
\left(\mathrm{A}_{2}\right)\end{array}$ \\
\hline 1 jam( $\left(\mathrm{B}_{1}\right)$ & $3,961^{\mathrm{abc}}$ & $3,038^{\mathrm{a}}$ \\
2 jam( $\left.\mathrm{B}_{2}\right)$ & $3,884^{\mathrm{abc}}$ & $3,692^{\mathrm{abc}}$ \\
3 jam( $\left.\mathrm{B}_{3}\right)$ & $4,153^{\mathrm{b}}$ & $4,615^{\mathrm{b}}$ \\
4 jam( $\left(\mathrm{B}_{4}\right)$ & $4,346^{\mathrm{b}}$ & $4,423^{\mathrm{b}}$ \\
\hline \hline
\end{tabular}

Hasil analisa statistik yang dilakukan dengan tingkat ketelitian 95 persen pada Tabel 3 menunjukkan bahwa perlakuan awal bahan baku, waktu destilasi, serta interaksi antar keduanya yang berbeda memberikan pengaruh yang berbeda terhadap intensitas aroma lemon minyak serai dapur yang dihasilkan. Perlakuan awal bahan baku dengan dirajang menunjukkan nilai intensitas aroma lemon yang lebih tinggi jika dibandingkan dengan dimemarkan.

Perlakuan dengan dirajang menunjukkan nilai intensitas aroma lemon yang lebih tinggi jika dibandingkan dengan dimemarkan. Dengan perlakuan perajangan dan dengan waktu destilasi yang semakin lama menyebabkan terjadinya peningkatan intensitas aroma lemon minyak serai dapur yang lebih signifikan jika dibandingkan dengan perlakuan dengan dimemarkan pada tingkat waktu destilasi yang sama. Pengecilan ukuran dengan perlakuan perajangan cenderung akan meningkatkan luas permukaan kontak antara bahan berminyak dengan pelarut sehingga senyawa sitral akan semakin mudah terekstrak, senyawa sitral inilah yang akan meningkatkan aroma lemon pada minyak yang dihasilkan. Minyak dari hasil perlakuan dirajang menunjukkan intensitas aroma lemon yang lebih tinggi dibandingkan dengan dimemarkan.

Peningkatan intensitas aroma minyak seiring dengan peningkatan waktu destilasi dapat terjadi karena semakin lama waktu destilasi maka semakin lama juga waktu kontak bahan dengan minyak sehingga semakin banyak senyawa sitral yang akan terekstrak. senyawa sitral inilah yang akan meningkatkan aroma lemon pada minyak yang dihasilkan.

Interaksi antara keduanya, yaitu perlakuan awal bahan baku dan waktu destilasi yang berbeda menghasilkan nilai absorbansi warna yang berbeda nyata, namun perbedaannya tidak terlalu signifikan.

Pada penelitian ini, nilai intensitas aroma minyak serai dapur yang dihasilkan berkisar antara 3,038-4,423, sedangkan menurut standar EOA yang dipersyaratkan aroma lemonnya kuat (EOA, 1975) dan menurut standar SNI yang dipersyaratkan aroma lemonnya kuat (SNI, 1995). Hasil penelitian menunjukkan kisaran intensitas aroma lemon sebesar 3,038-4,423, kalau dibandingkan dengan perlakuan essense lemon maka konsentrasi ekstrak lemon yang memenuhi nilai tersebut adalah konsentrasi III: $39,648 \%$; IV: 52,856 \% dan V: 66,080 $\%$. Dari beberapa perlakuan awal bahan baku dan waktu destilasi minyak serai dapur semua memenuhi standar mutu EOA maupun SNI yaitu aroma lemonnya kuat.

\section{Rendemen}

Rendemen merupakan kadar minyak atsiri di dalam serai dapur yang dinyatakan dalam persen.

Tabel 4. Hasil analisa rendemen minyak serai dapur (\%)

\begin{tabular}{ccc}
\hline \hline Waktu & \multicolumn{2}{c}{ Perlakuan awal bahan baku(A) } \\
\cline { 2 - 3 } destilasi (B) & $\begin{array}{c}\text { Dimemarkan } \\
\left(\mathrm{A}_{1}\right)\end{array}$ & Dirajang $\left(\mathrm{A}_{2}\right)$ \\
\hline 1 jam $\left(\mathrm{B}_{1}\right)$ & $0,068^{\mathrm{a}}$ & $0,076^{\mathrm{b}}$ \\
2 jam $\left(\mathrm{B}_{2}\right)$ & $0,163^{\mathrm{c}}$ & $0,181^{\mathrm{d}}$ \\
3 jam $\left(\mathrm{B}_{3}\right)$ & $0,258^{\mathrm{e}}$ & $0,301^{\mathrm{f}}$ \\
4 jam $\left(\mathrm{B}_{4}\right)$ & $0,300^{\mathrm{f}}$ & $0,303^{\mathrm{f}}$ \\
\hline \hline
\end{tabular}


Hasil analisa statistik yang dilakukan dengan tingkat ketelitian 95 persen pada Tabel 4 menunjukkan bahwa perlakuan awal bahan baku, waktu destilasi, serta interaksi antar keduanya yang berbeda memberikan pengaruh yang berbeda terhadap rendemen minyak serai dapur yang dihasilkan. Perlakuan awal bahan baku dengan dirajang menunjukkan rendemen yang lebih tinggi jika dibandingkan dengan dimemarkan.

Perlakuan dengan dirajang menunjukkan nilai rendemen yang lebih tinggi jika dibandingkan dengan dimemarkan. Dengan perlakuan perajangan dan dengan waktu destilasi yang semakin lama menyebabkan terjadinya peningkatan nilai rendemen minyak serai dapur yang lebih signifikan jika dibandingkan dengan perlakuan dengan dimemarkan pada tingkat waktu destilasi yang sama. Dengan perlakuan perajangan bentuk bahan menjadi lebih seragam, kompak dan merata sehingga dapat meningkatkan efisiensi ruang tempat destilasi. Apabila bahan kompak dan merata maka penggunaan air mendidih untuk berpenetrasi/difusi ke bahan menjadi lebih efisien. Menurut lucyana dan Sumarsi (1993), perlakuan perajangan menyebabkan proses hidrodifusi berjalan lebih cepat sehingga memperbesar jumlah minyak atsiri yang dihasilkan sedangkan menurut Ketaren (1987) dan Lucyana dan Sumarsi (1993), perajangan dapat memperluas/memperbesar luas permukaan kontak antara bahan berminyak dengan pelarut menjadi lebih besar dan merata sehingga minyak akan lebih mudah terekstrak, serta jumlahnya lebih banyak. Hal ini karena air mendidih membantu proses difusi pelarut ke bahan berminyak sehingga difusi tersebut akan merusak sebagian dinding sel bahan dan jaringan lemak yang melindungi kantungkantung/kelenjar minyak. Kondisi itulah yang menyebabkan minyak menjadi lebih mudah dan cepat terekstrak.

Peningkatan rendemen minyak seiring dengan peningkatan waktu destilasi disebabkan karena semakin lama waktu kontak antara bahan sumber minyak dengan pelarut sehingga minyak menjadi lebih mudah terekstrak, selain itu penambahan waktu destilasi menyebabkan proses hidrodifusi/penetrasi air mendidih ke bahan berlangsung lebih lama sehingga semakin banyak minyak yang dihasilkan (Lucyana dan Sumarsi, 1993). Semakin lama waktu destilasi maka semakin besar rendemen minyak serai dapur yang dihasilkan.

Interaksi antara keduanya, yaitu perlakuan awal bahan baku dan waktu destilasi yang berbeda menghasilkan nilai rendemen yang berbeda nyata, namun perbedaannya tidak terlalu signifikan.

Pada penelitian ini, rendemen minyak serai dapur yang dihasilkan berkisar antara 0,068-0,303\%, sedangkan menurut standar EOA nilai yang dipersyaratkan antara 0,2-0,4 $\%(E O A, 1975)$ dan menurut standar SNI nilai yang dipersyaratkan minimal 0,3 $\%($ SNI, 1995). Dari beberapa perlakuan awal bahan baku dan waktu destilasi minyak serai dapur yang masih memenuhi standar mutu EOA maupun SNI antara lain; Perlakuan dimemarkan dengan waktu destilasi selama 4 jam, perlakuan perajangan dengan waktu destilasi selama 3 dan 4 jam.

\section{Berat Jenis Pada Suhu $25^{\circ} \mathrm{C}$}

Berat jenis minyak atsiri merupakan perbandingan antara berat minyak atsiri dengan berat air dalam volume dan suhu yang sama(Guenther, 1948). Berat jenis minyak dipengaruhi oleh komponenkomponen penyusun minyak atsiri. Semakin banyak komponen berantai panjang atau senyawa polimer dalam minyak maka akan meningkatkan nilai densitas minyak.

Tabel 5. Hasil analisa berat jenis minyak serai dapur $(\mathrm{gr} / \mathrm{ml})$

\begin{tabular}{ccc}
\hline \hline \multirow{2}{*}{$\begin{array}{c}\text { Waktu } \\
\text { destilasi(B) }\end{array}$} & \multicolumn{2}{c}{$\begin{array}{c}\text { Perlakuan awal bahan } \\
\text { baku(A) }\end{array}$} \\
\cline { 2 - 3 } & $\begin{array}{c}\text { Dimemarkan } \\
\left(\mathrm{A}_{1}\right)\end{array}$ & $\begin{array}{c}\text { Dirajang } \\
\left(\mathrm{A}_{2}\right)\end{array}$ \\
\hline 1 jam $\left(\mathrm{B}_{1}\right)$ & $0,8374^{\mathrm{a}}$ & $0,8474^{\mathrm{b}}$ \\
2 jam $\left(\mathrm{B}_{2}\right)$ & $0,8497^{\mathrm{b}}$ & $0,8565^{\mathrm{c}}$ \\
3 jam $\left(\mathrm{B}_{3}\right)$ & $0,8637^{\mathrm{d}}$ & $0,8705^{\mathrm{e}}$ \\
4 jam $\left(\mathrm{B}_{4}\right)$ & $0,8726^{\mathrm{e}}$ & $0,8796^{\mathrm{f}}$ \\
\hline
\end{tabular}


pengaruh yang berbeda terhadap berat jenis minyak serai dapur yang dihasilkan. Perlakuan awal bahan baku dengan dirajang menunjukkan berat jenis yang lebih tinggi jika dibandingkan dengan dimemarkan.

Perlakuan dengan dirajang menunjukkan nilai berat jenis yang lebih tinggi jika dibandingkan dengan dimemarkan. Dengan perlakuan perajangan cenderung lebih memudahkan difusi pelarut ke bahan dan proses pengeluaran minyak atsiri yang terdapat dalam kelenjar minyak ke permukaan bahan. Menurut Ketaren (1987), pengecilan ukuran dengan perajangan menyebabkan terikutnya sejumlah senyawa-senyawa bertitik didih tinggi seperti; resin, parafin, lilin (wax) dan lemak dari kelenjar minyak lalu bercampur dan larut bersama minyak atsiri, kemudian ikut terdestilasi. Parafin dan lilin (wax) merupakan senyawa berantai panjang yang termasuk dalam golongan senyawa alkana dan senyawa tersebut mempunyai berat molekul dan titik didih yang tinggi sehingga akan meningkatkan nilai berat jenis pada minyak yang dihasilkan.

Peningkatan berat jenis minyak seiring dengan peningkatan waktu destilasi dapat terjadi karena proses destilasi dimana laju destilasi dipengaruhi oleh komponenkomponen kimia yang terkandung di dalam minyak atsiri. Komponen-komponen yang mempunyai titik didih tinggi membutuhkan waktu yang lebih lama untuk terdestilasi jika dibandingkan dengan komponen-komponen bertitik didih rendah. Semakin lama waktu destilasi akan terjadi peningkatan konsentrasi minyak yang disebabkan oleh semakin banyak terakumulasinya komponenkomponen kimia penyusun minyak atsiri, baik itu senyawa bertitik didih tinggi atau rendah, sehingga akan meningkatkan berat jenis minyak seiring dengan bertambahnya waktu destilasi. Peningkatan berat jenis minyak juga dapat terjadi karena proses pemanasan yang berlangsung selama proses destilasi. Pemanasan menyebabkan sebagian kecil komponen minyak atsiri mengalami polimerisasi. Komponen-komponen minyak atsiri yang mengalami polimerisasi adalah dari golongan senyawa hidrokarbon takteroksigenasi seperti; senyawa terpen dan sesquiterpen. Polimerisasi minyak menyebabkan terbentuknya senyawasenyawa polimer dalam minyak yang akan memicu meningkatkan nilai berat jenis minyak. Selain karena proses polimerisasi, peningkatan berat jenis minyak juga disebabkan oleh sejumlah kecil fraksi berat ikut tersuling selama proses destilasi. Menurut Feryanto (2006), pemanasan dengan suhu dan tekanan yang tinggi akan menyebabkan sejumlah komponen senyawa berantai panjang yang memiliki titik didih tinggi menjadi ikut tersuling bersama minyak. Fraksi berat tersebut seperti; parafin, lilin (wax) dan senyawa resin. Parafin merupakan senyawa dari golongan alkana berantai panjang yang terdapat dalam jaringan lemak tanaman aromatik kemudian larut bersama minyak atsiri. Semakin lama waktu destilasi maka akan meningkatkan berat jenis minyak.

Interaksi antara keduanya, yaitu perlakuan awal bahan baku dan waktu destilasi yang berbeda menghasilkan nilai rendemen yang berbeda nyata, namun perbedaannya tidak terlalu signifikan.

Pada penelitian ini, berat jenis minyak serai dapur yang dihasilkan berkisar antara 0,8374-0,8796 gr/ml, sedangkan menurut standar EOA nilai yang dipersyaratkan antara 0,8-0,9 gr/ml (EOA, 1975) dan menurut standar SNI nilai yang dipersyaratkan minimal $0,8731 \mathrm{gr} / \mathrm{ml}$ (SNI, 1995). Dari beberapa perlakuan awal bahan baku dan waktu destilasi minyak serai dapur semua memenuhi standar mutu EOA maupun SNI.

\section{Putaran optik}

Sifat optik dari minyak atsiri ditentukan menggunakan alat polarimeter yang nilainya dinyatakan dengan derajat rotasi. Sebagian besar minyak atsiri jika ditempatkan dalam cahaya yang dipolarisasikan maka memiliki sifat memutar bidang polarisasi ke arah kanan (dextrorotary) atau ke arah kiri (laevorotary). Pengukuran parameter ini sangat menentukan kriteria kemurnian suatu minyak atsiri. 
Tabel 6. Hasil analisa putaran optik minyak serai dapur

\begin{tabular}{ccc}
\hline \hline Waktu & \multicolumn{2}{c}{ Perlakuan awal bahan baku(A) } \\
\cline { 2 - 3 } destilasi(B) & $\begin{array}{c}\text { Dimemarkan } \\
\left(\mathrm{A}_{1}\right)\end{array}$ & $\begin{array}{c}\text { Dirajang } \\
\left(\mathrm{A}_{2}\right)\end{array}$ \\
\hline 1 jam($\left(\mathrm{B}_{1}\right)$ & $+0,14^{\mathrm{a}}$ & $+0,14^{\mathrm{a}}$ \\
2 jam $\left(\mathrm{B}_{2}\right)$ & $+0,15^{\mathrm{a}}$ & $+0,17^{\mathrm{b}}$ \\
3 jam $\left(\mathrm{B}_{3}\right)$ & $+0,18^{\mathrm{b}}$ & $+0,20^{\mathrm{c}}$ \\
4 jam $\left(\mathrm{B}_{4}\right)$ & $+0,20^{\mathrm{c}}$ & $+0,21^{\mathrm{d}}$ \\
\hline \hline
\end{tabular}

Hasil analisa statistik yang dilakukan dengan tingkat ketelitian 95 persen pada Tabel 6 menunjukkan bahwa perlakuan awal bahan baku, waktu destilasi, serta interaksi antar keduanya yang berbeda memberikan pengaruh yang berbeda terhadap nilai putaran optik minyak serai dapur yang dihasilkan. Perlakuan awal bahan baku dengan dirajang menunjukkan nilai putaran optik yang lebih tinggi jika dibandingkan dengan dimemarkan.

Perlakuan dengan dirajang menunjukkan nilai putaran optik yang lebih tinggi jika dibandingkan dengan dimemarkan. Dengan perlakuan perajangan cenderung lebih memudahkan difusi pelarut ke bahan dan proses pengeluaran minyak atsiri yang terdapat dalam kelenjar minyak ke permukaan bahan. Menurut Ketaren (1987), pengecilan ukuran dengan perajangan menyebabkan terikutnya sejumlah senyawa-senyawa bertitik didih tinggi seperti; resin, parafin, lilin (wax) dan lemak dari kelenjar minyak lalu bercampur dan larut bersama minyak atsiri, kemudian ikut terdestilasi, sehingga akan meningkatkan kerapatan medium minyak yang dihasilkan. apabila ada cahaya yang datang dari medium yang kurang rapat (udara) maka akan lebih mudah untuk dibiaskan. Apabila cahaya yang terpolarisasi bidang dilewatkan dalam medium/zat optik (minyak serai dapur) maka cahaya tersebut akan memutar kekiri atau ke kanan dengan sudut putar tertentu. Dengan meningkatnya nilai kerapatan dari zat optik tersebut maka sudut putar dari rotasi optik minyak serai dapur tersebut juga akan meningkat.

Peningkatan nilai putaran optik minyak seiring dengan peningkatan waktu destilasi dapat terjadi karena proses pemanasan yang berlangsung selama proses destilasi. Pemanasan menyebabkan sebagian kecil komponen minyak atsiri mengalami polimerisasi. Komponen-komponen minyak atsiri yang mengalami polimerisasi adalah dari golongan senyawa hidrokarbon takteroksigenasi seperti; senyawa terpen dan sesquiterpen. Polimerisasi minyak menyebabkan terbentuknya senyawasenyawa polimer dalam minyak yang akan memicu meningkatkan nilai putaran optik minyak. Selain karena proses polimerisasi, peningkatan nilai putaran optik minyak juga disebabkan oleh sejumlah kecil fraksi berat ikut tersuling selama proses destilasi. Menurut Feryanto (2006), pemanasan dengan suhu dan tekanan yang tinggi akan menyebabkan sejumlah komponen senyawa berantai panjang yang memiliki titik didih tinggi menjadi ikut tersuling bersama minyak. Fraksi berat tersebut seperti; parafin, lilin (wax) dan senyawa resin. Parafin merupakan senyawa dari golongan alkana berantai panjang yang terdapat dalam jaringan lemak tanaman aromatik kemudian larut bersama minyak atsiri. Semakin lama waktu destilasi maka akan meningkatkan kerapatan medium minyak sehingga akan meningkatkan nilai derajat rotasi optik minyak.

Interaksi antara keduanya, yaitu perlakuan awal bahan baku dan waktu destilasi yang berbeda menghasilkan nilai putaran optik yang berbeda nyata, namun perbedaannya tidak terlalu signifikan.

Pada penelitian ini, nilai putaran optik minyak serai dapur yang dihasilkan berkisar antara $+0,14$ sampai $+0,21$, sedangkan menurut standar EOA nilai yang dipersyaratkan antara -3 sampai +1 (EOA, 1975) dan menurut standar SNI nilai yang dipersyaratkan minimal +0,2 (SNI, 1995). Dari beberapa perlakuan awal bahan baku dan waktu destilasi minyak serai dapur semua memenuhi standar mutu EOA, yang memenuhi standar SNI yakni; pada perlakuan perajangan dengan waktu destilasi selama 3 dan 4 jam, serta pada dimemarkan dengan waktu destilasi selama 4 jam.

\section{Indek bias}

Indek bias merupakan perbandingan antara kecepatan cahaya di udara dengan 
kecepatan cahaya di dalam suatu medium/zat pada suhu tertentu.

Tabel 7. Hasil analisa indek bias pada $20{ }^{\circ} \mathrm{C}$ minyak serai dapur

\begin{tabular}{|c|c|c|}
\hline \multirow[t]{2}{*}{$\begin{array}{c}\text { Waktu } \\
\text { destilasi(B) }\end{array}$} & \multicolumn{2}{|c|}{$\begin{array}{c}\text { Perlakuan awal bahan } \\
\text { baku(A) }\end{array}$} \\
\hline & $\begin{array}{c}\text { Dimemarkan } \\
\left(\mathrm{A}_{1}\right)\end{array}$ & $\begin{array}{c}\text { Dirajang } \\
\left(\mathrm{A}_{2}\right)\end{array}$ \\
\hline $1 \mathrm{jam}\left(\mathrm{B}_{1}\right)$ & $1,4468^{\mathrm{a}}$ & $1,4469^{\mathrm{a}}$ \\
\hline $2 \mathrm{jam}\left(\mathrm{B}_{2}\right)$ & $1,4486^{\mathrm{b}}$ & $1,4494^{\mathrm{b}}$ \\
\hline $3 \mathrm{jam}\left(\mathrm{B}_{3}\right)$ & $1,4513^{\mathrm{c}}$ & $1,4545^{\mathrm{d}}$ \\
\hline $4 \mathrm{jam}\left(\mathrm{B}_{4}\right)$ & $1,4548^{\mathrm{d}}$ & $1,4575^{\mathrm{e}}$ \\
\hline
\end{tabular}

Hasil analisa statistik yang dilakukan dengan tingkat ketelitian 95 persen pada Tabel 7 menunjukkan bahwa perlakuan awal bahan baku, waktu destilasi, serta interaksi antar keduanya yang berbeda memberikan pengaruh yang berbeda terhadap nilai indeks bias minyak serai dapur yang dihasilkan. Perlakuan awal bahan baku dengan dirajang menunjukkan nilai indeks bias yang lebih tinggi jika dibandingkan dengan dimemarkan.

Perlakuan dengan dirajang menunjukkan nilai indeks bias yang lebih tinggi jika dibandingkan dengan dimemarkan. Dengan perlakuan perajangan cenderung lebih memudahkan difusi pelarut ke bahan dan proses pengeluaran minyak atsiri yang terdapat dalam kelenjar minyak ke permukaan bahan. Menurut Ketaren (1987), pengecilan ukuran dengan perajangan menyebabkan terikutnya sejumlah senyawa-senyawa bertitik didih tinggi seperti; resin, parafin, lilin (wax), dan lemak dari kelenjar minyak lalu bercampur dan larut bersama minyak atsiri, kemudian ikut terdestilasi, sehingga akan meningkatkan kerapatan medium minyak yang dihasilkan. Apabila seberkas cahaya merambat dari medium kurang rapat menuju medium yang lebih rapat maka cahaya tersebut akan dibiaskan maka semakin besar juga nilai sudut biasnya.

Peningkatan index bias minyak seiring dengan peningkatan waktu destilasi dapat terjadi karena proses pemanasan yang berlangsung selama proses destilasi. Pemanasan menyebabkan sebagian kecil komponen minyak atsiri mengalami polimerisasi. Komponen-komponen minyak atsiri yang mengalami polimerisasi adalah dari golongan senyawa hidrokarbon takteroksigenasi seperti; senyawa terpen dan sesquiterpen. Polimerisasi minyak menyebabkan terbentuknya senyawasenyawa polimer dalam minyak yang akan memicu meningkatkan nilai index bias minyak. Selain karena proses polimerisasi, peningkatan index bias minyak juga disebabkan oleh sejumlah kecil fraksi berat ikut tersuling selama proses destilasi. Menurut Feryanto (2006), pemanasan dengan suhu dan tekanan yang tinggi akan menyebabkan sejumlah komponen senyawa berantai panjang yang memiliki titik didih tinggi menjadi ikut tersuling bersama minyak. Fraksi berat tersebut seperti; parafin, lilin (wax), dan senyawa resin. Parafin merupakan senyawa dari golongan alkana berantai panjang yang terdapat dalam jaringan lemak tanaman aromatik kemudian larut bersama minyak atsiri. Semakin lama waktu destilasi maka akan meningkatkan kerapatan medium minyak sehingga akan meningkatkan nilai index bias minyak.

Interaksi antara keduanya, yaitu perlakuan awal bahan baku dan waktu destilasi yang berbeda menghasilkan nilai indeks bias yang berbeda nyata, namun perbedaannya tidak terlalu signifikan.

Pada penelitian ini, indek bias minyak serai dapur yang dihasilkan berkisar antara 1,4468-1,4575, sedangkan menurut standar EOA nilai yang dipersyaratkan antara 1,4830 - 1,4890 (EOA, 1975) dan menurut standar SNI nilai yang dipersyaratkan minimal 1,4587 (SNI, 1995). Dari beberapa perlakuan awal bahan baku dan waktu destilasi minyak serai dapur semua tidak memenuhi standar SNI maupun EOA.

\section{Kelarutan dalam Alkohol 70 \%}

Kelarutan minyak serai dapur dalam alkohol memberikan gambaran mudah/tidaknya suatu minyak larut dalam alkohol. Kelarutan dalam alkohol dinyatakan dalam jumlah alkohol yang dibutuhkan untuk melarutkan $1 \mathrm{ml}$ minyak serai dapur.

Hasil analisa statistik yang dilakukan dengan tingkat ketelitian 95 persen pada Tabel 8 menunjukkan bahwa perlakuan awal 
bahan baku, waktu destilasi, serta interaksi antar keduanya yang berbeda memberikan pengaruh yang berbeda terhadap nilai kelarutan minyak dalam alkohol minyak serai dapur yang dihasilkan. Perlakuan awal bahan baku dengan dirajang menunjukkan nilai kelarutan minyak dalam alkohol yang lebih rendah jika dibandingkan dengan dimemarkan.

Tabel 8. Hasil analisa kelarutan minyak serai dapur dalam alkohol $70 \%$

\begin{tabular}{ccc}
\hline \hline \multirow{3}{*}{ Waktu } & \multicolumn{2}{c}{ Perlakuan awal bahan baku(A) } \\
\cline { 2 - 3 } destilasi(B) & Dimemarkan $\left(\mathrm{A}_{1}\right)$ & Dirajang $\left(\mathrm{A}_{2}\right)$ \\
\hline 1 jam $\left(\mathrm{B}_{1}\right)$ & $1: 3^{\mathrm{c}}$ & $1: 3^{\mathrm{c}}$ \\
2 jam $\left(\mathrm{B}_{2}\right)$ & $1: 3^{\mathrm{c}}$ & $1: 3,33 b^{\mathrm{c}}$ \\
3 jam $\left(\mathrm{B}_{3}\right)$ & $1: 3,66^{\mathrm{ab}}$ & $1: 4^{\mathrm{a}}$ \\
4 jam $\left(\mathrm{B}_{4}\right)$ & $1: 4^{\mathrm{a}}$ & $1: 4,33^{\mathrm{a}}$ \\
\hline \hline
\end{tabular}

Perlakuan dengan dirajang menunjukkan nilai kelarutan minyak dalam alkohol yang lebih rendah jika dibandingkan dengan dimemarkan. Dengan perlakuan perajangan dan dengan waktu destilasi yang semakin lama menyebabkan terjadinya penurunan nilai kelarutan minyak dalam alkohol yang lebih signifikan jika dibandingkan dengan perlakuan dengan dimemarkan pada tingkat waktu destilasi yang sama. Dengan perlakuan perajangan lebih memudahkan difusi pelarut ke bahan dan proses pengeluaran minyak atsiri yang terdapat dalam kelenjar minyak ke permukaan bahan. Menurut Ketaren (1987), pengecilan ukuran dengan perajangan menyebabkan terikutnya sejumlah senyawasenyawa bertitik didih tinggi seperti; resin, parafin, lilin (wax) dan lemak dari kelenjar minyak lalu bercampur dan larut bersama minyak atsiri, kemudian ikut terdestilasi, sehingga akan menurunkan kelarutan minyak yang dihasilkan. Senyawa resin, parafin, lilin merupakan senyawa non-polar yang bersifat tidak mudah larut dalam alkohol. Alkohol sendiri merupakan senyawa polar, dimana senyawa polar bersifat saling melarutkan senyawa polar dan bersifat tidak saling larut dengan senyawa non-polar. Semakin banyak kandungan senyawa non-polar dalam minyak maka akan menurunkan kelarutan minyak dalam alkohol.
Penurunan kelarutan minyak seiring dengan peningkatan waktu destilasi dapat terjadi karena proses pemanasan yang berlangsung selama proses destilasi. Pemanasan menyebabkan sebagian kecil komponen minyak atsiri mengalami polimerisasi. Komponen-komponen minyak atsiri yang mengalami polimerisasi adalah dari golongan senyawa hidrokarbon takteroksigenasi seperti; senyawa terpen dan sesquiterpen. Polimerisasi minyak menyebabkan terbentuknya senyawasenyawa polimer dalam minyak yang akan memicu menurunkan nilai kelarutan minyak dalam alkohol. Selain karena proses polimerisasi, penurunan kelarutan minyak dalam alkohol juga disebabkan oleh sejumlah kecil fraksi berat ikut tersuling selama proses destilasi. Pemanasan dengan suhu dan tekanan yang tinggi akan menyebabkan sejumlah komponen senyawa berantai panjang yang memiliki titik didih tinggi menjadi ikut tersuling bersama minyak. Fraksi berat tersebut seperti; parafin, lilin (wax) dan senyawa resin. Semakin lama waktu destilasi maka akan menurunkan kelarutan minyak. Menurut Widada (1993), Penurunan kelarutan minyak dalam alkohol tergantung pada jenis komponen-komponen kimia yang terkandung dalam minyak. Semakin banyak komponen senyawa yang mengandung gugus $\mathrm{OH}$ maka semakin tinggi kelarutannya, sebaliknya semakin sedikit senyawa yang mengandung gugus $\mathrm{OH}$ dan semakin tinggi kandungan senyawa terpennya maka semakin rendah kelarutannya. Senyawa-senyawa non-polar seperti senyawa terpen, sesquiterpen, resin, parafin, lilin mempunyai sifat tidak mudah larut dalam pelarut alkohol. Minyak atsiri yang banyak mengandung senyawa hidrokarbon teroksigenasi lebih mudah larut dalam alkohol dan hidrokarbon takteroksigenasi tidak mudah larut dalam alkohol. Kelarutan tersebut didasarkan pada tingkat kepolaran suatu senyawa yang menyusun minyak atsiri.

Interaksi antara keduanya, yaitu perlakuan awal bahan baku dan waktu destilasi yang berbeda menghasilkan nilai kelarutan dalam alkohol yang berbeda nyata, namun perbedaannya tidak terlalu signifikan. 
Pada penelitian ini, kelarutan minyak serai dapur dalam alkohol $70 \%$ yang dihasilkan berkisar antara 1:3 sampai 1 : 4,33, sedangkan menurut standar EOA nilai yang dipersyaratkan antara $1: 2$ sampai $1: 4$ (EOA, 1975) dan menurut standar SNI nilai yang dipersyaratkan maksimal 1 : 4 (SNI, 1995). Dari beberapa perlakuan awal bahan baku dan waktu destilasi minyak serai dapur yang tidak memenuhi standar mutu EOA maupun SNI hanya pada perlakuan perajangan dengan waktu destilasi selama 4 jam saja.

\section{Kadar Sitral}

Sitral merupakan senyawa aktif yang terdapat dalam minyak serai dapur. Sitral adalah senyawa aldehid yang memberikan bau khas lemon dari minyak serai dapur.

Hasil analisa statistik yang dilakukan dengan tingkat ketelitian 95 persen pada Tabel 9 menunjukkan bahwa perlakuan awal bahan baku, waktu destilasi, serta interaksi antar keduanya yang berbeda memberikan pengaruh yang berbeda terhadap nilai kadar sitral minyak serai dapur yang dihasilkan. Perlakuan awal bahan baku dengan dirajang menunjukkan nilai kadar sitral yang lebih tinggi jika dibandingkan dengan dimemarkan.

Tabel 9. Hasil analisa kadar sitral minyak serai dapur (\%)

\begin{tabular}{ccc}
\hline \hline \multirow{2}{*}{$\begin{array}{c}\text { Waktu } \\
\text { destilasi (B) }\end{array}$} & $\begin{array}{c}\text { Perlakuan awal bahan baku } \\
(\mathrm{A})\end{array}$ \\
\cline { 2 - 3 } & $\begin{array}{c}\text { Dimemarkan } \\
\left(\mathrm{A}_{1}\right)\end{array}$ & $\begin{array}{c}\text { Dirajang } \\
\left(\mathrm{A}_{2}\right)\end{array}$ \\
\hline 1 jam $\left(\mathrm{B}_{1}\right)$ & $70,0^{\mathrm{a}}$ & $70,0^{\mathrm{a}}$ \\
2 jam $\left(\mathrm{B}_{2}\right)$ & $73,3^{\mathrm{b}}$ & $74,0^{\mathrm{b}}$ \\
3 jam $\left(\mathrm{B}_{3}\right)$ & $75,3^{\mathrm{c}}$ & $76,3^{\mathrm{c}}$ \\
4 jam $\left(\mathrm{B}_{4}\right)$ & $76,3^{\mathrm{c}}$ & $76,3^{\mathrm{c}}$ \\
\hline \hline
\end{tabular}

Perlakuan dengan dirajang menunjukkan nilai kadar sitral yang lebih tinggi jika dibandingkan dengan dimemarkan. Dengan perlakuan perajangan cenderung lebih memudahkan difusi pelarut ke bahan dan proses pengeluaran minyak atsiri yang terdapat dalam kelenjar minyak ke permukaan bahan. Pengecilan ukuran dengan perajangan akan memperbesar luas permukaan kontak antara bahan berminyak dengan pelarut sehingga semakin banyak senyawa sitral yang akan terekstraksi.

Peningkatan kadar sitral minyak seiring dengan peningkatan waktu destilasi dapat terjadi karena semakin lama waktu kontak antara bahan sumber minyak dengan pelarut sehingga sitral menjadi lebih mudah terekstrak, selain itu proses pemanasan yang berlangsung cukup lama dan dalam kondisi yang lembab akan mengakibatkan reaksi hidrolisis sebagian dari komponen minyak seperti senyawa sitronelol dan sitronelal menjadi sitral lebih sempurna sehingga akan memperbesar kadar sitral yang dihasilkan.

Interaksi antara keduanya, yaitu perlakuan awal bahan baku dan waktu destilasi yang berbeda menghasilkan nilai kadar sitral yang berbeda nyata, namun perbedaannya tidak terlalu signifikan.

Pada penelitian ini, kadar sitral minyak serai dapur yang dihasilkan berkisar antara 70,0-76,3 \%, sedangkan menurut standar EOA nilai yang dipersyaratkan antara 75-80 \% (EOA, 1975) dan menurut standar SNI nilai yang dipersyaratkan minimal 76,1 \% (SNI, 1995). Dari beberapa perlakuan awal bahan baku dan waktu destilasi minyak serai dapur yang masih memenuhi standar mutu EOA maupun SNI antara lain; perlakuan dimemarkan dengan waktu destilasi selama 4 jam, perlakuan perajangan dengan waktu destilasi selama 3 dan 4 jam.

\section{KESIMPULAN}

Berdasarkan hasil penelitian yang telah dilakukan maka dapat ditarik kesimpulan sebagai berikut. Perlakuan dimemarkan dan dirajang tidak mempengaruhi warna dan kadar sitral, tetapi mempengaruhi nilai Total padatan terlarut, aroma, rendemen, berat jenis, putaran optik, index bias dan kelarutan dalam alkohol. Perlakuan perajangan menghasilkan nilai Total padatan terlarut, aroma, rendemen, berat jenis, putaran optik, indek bias yang lebih tinggi jika dibandingkan dengan dimemarkan sedangkan kelarutannya dalam alkohol cenderung lebih rendah, kemudian perlakuan awal bahan baku dengan perajangan merupakan perlakuan yang paling optimal untuk menghasilkan minyak serai 
dapur yang lebih baik, yakni; dengan nilai total padatan terlarut $80,533{ }^{\circ}$ Brix, warna $0,5456 \AA$, aroma lemon, rendemen $0,303 \%$, berat jenis pada $25^{\circ} \mathrm{C} 0,8796 \mathrm{gr} / \mathrm{ml}$, putaran optic $+0,21$, indek bias pada $20{ }^{\circ} \mathrm{C} 1,4575$, kelarutan dalam alkohol $70 \% 1: 4,33$ dan kadar sitral 76,3 \%. Waktu destilasi berpengaruh terhadap karakteristik minyak serai dapur yang dihasilkan. Semakin lama waktu destilasi maka minyak serai dapur yang dihasilkan mempunyai nilai Total padatan terlarut, warna, aroma, rendemen, berat jenis, putaran optik, indek bias dan kadar sitral yang semakin tinggi, sedangkan kelarutannya dalam alkohol semakin rendah, kemudian waktu destilasi selama 4 jam merupakan perlakuan yang paling optimal untuk menghasilkan minyak serai dapur yang lebih baik, yakni; dengan nilai total padatan terlarut $80,533{ }^{\circ} \mathrm{Brix}$, warna $0,5456 \AA$, aroma lemon, rendemen $0,303 \%$, berat jenis pada $25{ }^{\circ} \mathrm{C} 0,8796 \mathrm{gr} / \mathrm{ml}$, putaran optic $+0,21$, indek bias pada $20{ }^{\circ} \mathrm{C} 1,4575$, kelarutan dalam alkohol $70 \% 1: 4,33$ dan kadar sitral $76,3 \%$. Interaksi antara keduanya yakni perlakuan awal bahan baku dan waktu destilasi berpengaruh terhadap Total padatan terlarut, aroma, rendemen, berat jenis, putaran optik, indek bias dan tidak berpengaruh terhadap warna dan kadar sitral. Dengan perlakuan perajangan dan waktu destilasi yang lebih lama menyebabkan terjadi peningkatan nilai Total padatan terlarut, aroma, rendemen, berat jenis, putaran optik, indek bias yang lebih signifikan dibandingkan dengan dimemarkan pada waktu destilasi yang sama, sedangkan kelarutannya dalam alkohol cenderung menurun.

\section{DAFTAR PUSTAKA}

Harris, Ruslan. 1993. Tanaman Minyak Atsiri. Penebar Swadaya. Jakarta.

Feryanto. 2006. Minyak Serai Dapur/Lemongrass Oil. http://ferryatsiri.blogspot.com/2006/10/minyakserai-dapur-lemongrass- oil.html . Diakses tgl 23 juli 2008.

Guenther, E. 1987. Minyak Atsiri Jilid I. UIPress. Jakarta.
SNI. 1995. Karakteristik Minyak Serai Dapur/Lemongrass oil. Badan Standarisasi Nasional. Jakarta.

EOA. 1975. Essential Oil Association of U.S.A., Inc, New York.

Ketaren, S. 1987. Minyak Atsiri Jilid I. UIPress. Jakarta.

Lucyana dan Sumarsi. 1993. Pengaruh Ukuran Bahan dan Waktu Penyulingan Terhadap Hasil dan Sifat Fisikokimia Minyak Lada Putih yang Dihasilakan. Warta IHP Vol 10 No. 1-2. Bogor.

Widada, H. D. 1993. Pengaruh pengecilan Ukuran Daun Gagang dan Bunga Cengkeh Terhadap Rendemen dan Kualitas Minyak yang Dihasilkan. Skripsi Fakultas Teknologi Pertanian UGM. Yogyakarta. 